\title{
Spot Survei Entomologi Malaria di Daerah Epidemi di Kabupaten Kotabaru Kalimantan Selatan
}

\author{
Muhammad Rasyid Ridha*, Budi Hairani, Abdullah Fadilly \\ Balai Litbangkes Tanah Bumbu, Kementerian Kesehatan RI, J1. Loka Litbang Kawasan Perkantoran Pemda Tanah Bumbu, \\ Kecamatan Batulicin, Kabupaten Tanah Bumbu, Kalimantan Selatan 72271, Indonesia \\ *Corresponding author: ridho.litbang@gmail.com
}

Info Artikel : Diterima 8 September 2020 ; Disetujui 17 Maret 2021 ; Publikasi 1 Oktober 2021

Cara sitasi (Vancouver): Ridha MR, Hairani B, Fadilly A. Spot Survei Entomologi Malaria di Daerah Epidemi di Kabupaten Kotabaru Kalimantan Selatan. Jurnal Kesehatan Lingkungan Indonesia [Online]. 2021 Oct;20(2):82-89. https://doi.org/10.14710/jkli.20.2.82-89.

\begin{abstract}
ABSTRAK
Latar belakang: Indonesia menargetkan eliminasi malaria pada tahun 2030. Kabupaten Kotabaru merupakan daerah endemis malaria. Salah satu Desa Endemis yaitu Desa Batang Kulur yang terjadi peningkatan kasus signifikan sebanyak 12 kasus pada Bulan Maret 2019. Tujuan penelitian ini adalah untuk mengukur indeks entomologi, karakteristik, dan lingkungan habitat perkembangbiakan vektor malaria di Desa Batang Kulur.

Metode: Kegiatan yang dilakukan yaitu penangkapan nyamuk dengan umpan orang, identifikasi dan pembedahan ovarium nyamuk untuk diketahui parusitas (pernah/tidak pernah bertelur) yang digunakan untuk memprediksi umur dan survei habitat perkembangbiakan vektor malaria.

Hasil: Spesies dan komposisi nyamuk yang ditemukan yaitu Aedes vexans, Aedes albopictus, Culex quinquefasciatus, Culex tritaeniorhynchus, Culex vishnui, Mansonia dives dan Anopheles leucosphyrus. Kepadatan nyamuk Anopheles leucosphyrus 0,30 dan kepadatan permalam yaitu 2,67 dengan peluang hidup perhari 95\% serta perkiraan umur populasi 21,54 hari. Fluktuasi Anopheles leucosphyrus mulai muncul pada jam 22.00 dan kembali meningkat pada jam 04.00. Tempat perindukan nyamuk yang ditemukan yaitu Habitat perkembang biakan nyamuk yang ditemukan ada 2 yaitu kolam dan mata air.

Simpulan: Terdapat habitat perkembang biakan yang mendukung, peluang hidup 95\% dan potensi umur nyamuk lebih dari masa inkubasi Plasmodium sehingga di Desa Batang Kulur merupakan daerah yang cocok untuk perkembangan vektor malaria.
\end{abstract}

Kata kunci: Malaria; wabah; Kotabaru; Anopheles leucosphyrus

\section{ABSTRACT}

Title: Investigation of Spot Survey of Malaria Entomological in Epedemic Areas in Kotabaru District, South Kalimantan

Background: Indonesia is targeting malaria elimination by 2030. Kotabaru Regency is a malaria endemic area. One of the endemic villages, Batang Kulur Village, saw a significant increase of 12 cases in March 2019. The purpose of this study was to measure the entomological index, characteristics, and environment of the malaria vector breeding habitat in Batang Kulur Village.

Method: Activities carried out include catching mosquitoes by baiting people, telephone and surgery for the mosquito ovaries to determine of parity (parous /nullyparous) which are used to predict age and survey the breeding habitats for malaria vectors.

Result: The mosquito species and composition found were Aedes vexans, Aedes albopictus, Culex quinquefasciatus, Culex tritaeniorhynchus, Culex vishnui, Mansonia dives and Anopheles leucosphyrus. The density of the Anopheles leucosphyrus was 0.30 and the per night density was 2.67 with a 95\% chance of 
survival per day and an estimated population age of 21.54 days. Anopheles leucosphyrus fluctuations began to appear at 22.00 and again increased at 04.00 . The mosquito breeding places found were 2 mosquito breeding habitats, namely ponds and springs.

Conclusion: There is a suitable breeding habitat, a 95\% chance of survival and a potential age of mosquitoes that is more than the plasmodium incubation period so that in Batang Kulur Village is a suitable area for the development of malaria vectors.

Keywords: Malaria; outbreak; Kotabaru; Anopheles leucosphyrus

\section{PENDAHULUAN}

Malaria merupakan penyakit tular vektor yang menjadi masalah kesehatan masyarakat, karena dapat menyebabkan kematian dan menurunkan produktifitas sumber daya manusia. Agen malaria yaitu parasit Plasmodium dan ditularkan melalui nyamuk Anopheles Spp. Secara global, penyebarannya sangat luas yaitu di wilayah antara garis bujur $60^{\circ}$ di utara dan $40^{\circ}$ di selatan, meliputi lebih dari 100 negara beriklim tropis dan sub tropis. ${ }^{1}$

Situasi malaria di Indonesia menunjukkan masih terdapat 10,7 juta penduduk yang tinggal di daerah endemis menengah dan tinggi malaria. Daerah tersebut terutama meliputi Papua, Papua Barat, dan NTT. Pada 2017, dari jumlah 514 kabupaten/kota di Indonesia, $266(52 \%)$ di antaranya wilayah bebas malaria, 172 kabupaten/kota (33\%) endemis rendah, 37 kabupaten/kota (7\%) endemis menengah, dan 39 kabupaten/kota (8\%) endemis tinggi. ${ }^{2}$

Kementerian Kesehatan (Kemenkes) menargetkan Indonesia bebas eliminasi malaria pada tahun 2030. Tahun 2016, jumlah kab/kota eliminasi malaria sebanyak 247 dari target 245, sedangkan 2017 pemerintah berhasil memperluas daerah eliminasi malaria yakni 266 kabupaten/kota dari target 265 kabupaten/kota. Sementara tahun 2018 ditargetkan sebanyak 285 kabupaten/kota yang berhasil mencapai eliminasi, dan 300 kabupaten/kota pada 2019. ${ }^{3}$ Selain itu, tidak ada lagi daerah endemis tinggi malaria di 2020. Tahun 2025 semua kabupaten/kota mencapai eliminasi, 2027 semua provinsi mencapai eliminasi, dan 2030 Indonesia mencapai eliminasi. Eliminasi malaria adalah upaya untuk menghentikan penularan malaria setempat dalam satu wilayah geografi tertentu. ${ }^{3,4}$

Secara umum, Kabupaten/Kota di Kalimantan Selatan sebanyak 53\% sudah bebas malaria. Angka Annual Parasite Incidance (API) di Kalimantan Selatan adalah 0,21 kurang dari $1 \%$ dan angka Slide Parasite Rate (SPR) adalah 3,0 atau kurang dari 5\% sehingga sudah masuk zona hijau. Namun beberapa kabupaten yang masih pada daerah kuning yaitu Tabalong dan Kotabaru.

Kabupaten Kotabaru secara adminitratif memiliki 28 Puskesmas, Data tahun 2018 masih ditemukan 22 Desa Endemis Malaria yaitu Kecamatan Pulau Sembilan (4 Desa); Kecamatan Kelumpang Barat (5 Desa); Sungai Durian (3 Desa); Pamukan Barat (3 Desa); Hampang (2 Desa); Kelumpang Hulu (2 Desa); Pulau Laut Selatan (2 Desa); dan Pulau Laut
Tengah (1 Desa). Desa Endemis terbanyak yaitu di Kecamatan Kelumpang Barat yaitu Desa Bungkukan, Batang Kulur, Siayuh, Magalau Hulu dan tanjung sari. Hingga bulan Juni 2019 di Desa Batang Kulur dilaporkan ada 20 kasus malaria. Peningkatan kasus secara signifikan terjadi di Bulan Maret 2019 sebanyak 12 kasus, sehingga dilaporkan sebagai epidemi dan kondisi tersebut menjadikan Kab. Kotabaru menjadi zona merah. ${ }^{5}$ Penularan tersebut diperkirakan dipicu dari masuknya pekerja baru yang membawa agen Plasmodium.

Secara alamiah, penularan malaria terjadi karena adanya interaksi antara agent (parasit Plasmodium Spp), host definitive (nyamuk Anopheles Spp) dan host intermediate (manusia). Karena itu, penularan malaria dipengaruhi oleh keberadaan dan fluktuasi populasi vektor (penular yaitu nyamuk Anopheles Spp), yang salah satunya dipengaruhi oleh intensitas curah hujan, serta sumber parasit Plasmodium Spp. atau penderita di samping adanya host yang rentan. ${ }^{6}$ Spesies Anopheles berpeluang menjadi vektor malaria apabila mempunya hidup yang panjang, kontak dengan manusia cukup tinggi, dan merupakan jenis yang dominan di lokasi yang tersebut. $^{7}$

Di Indonesia dijumpai lebih dari 90 spesies Anopheles Spp. dan yang telah diketahui menjadi vektor adalah sebanyak 18 spesies. Yang paling dikenal adalah Anopheles sundaicus, An. barbirostris, An. maculatus dan An. aconitus. ${ }^{8}$ Hasil penelitian terdahulu dengan pemeriksaan PCR membuktikan bahwa An. leucosphyrus merupakan vektor malaria baru di Kabupaten Kotabaru. ${ }^{9}$ 10, 11 An. leucosphyrus yang juga merupakan bagian dari An. leucosphyrus group diketahui sebagai vektor malaria knowlesi $(P$. knowlesi) pada Macaca fascicularis, Macaca nemestrina and Macaca leonina selain dari jenis An. dirus group. ${ }^{12}$ Pengamatan nyamuk Anopheles dan tempat habitatnya perlu dilakukan di Desa Haur Gading untuk mengetahui tersangka vektor yang berperan dalam penularan malaria. Tujuan penelitian ini adalah untuk mengukur indeks entomologi, karakteristik, dan lingkungan habitat perindukan vektor malaria di Desa Batang Kulur.Kabupaten Kotabaru.

\section{MATERI DAN METODE}

Jenis penelitian adalah observasional menggunakan metode survei dengan desain cross sectional yang dianalisis secara deskriptif. Penelitian 
ini merupakan survei entomologi malaria di daerah epidemi. Penelitian dilakukan di Desa Batang Kulur, Kecamatan Kelumpang Barat, Kabupaten Kotabaru pada tanggal $10-12$ Juli 2019 dengan koordinat $2^{0} 48^{\prime} 46,37^{\prime \prime} \mathrm{S}$ dan $116^{0} 04^{\prime} 20,36^{\prime \prime E}$. Kegiatan yang dilakukan yaitu penangkapan nyamuk pradewasa dan dewasa, observasi lingkungan dan habitat tempat perkembangbiakan nyamuk. Varibel yang diteliti yaitu suhu, kelembaban, jumlah nyamuk, spesies nyamuk, jenis habitat, $\mathrm{pH}$, salinitas, dan suhu air. Populasi adalah semua nyamuk yang ada di Desa Batang Kulur, Kecamatan Kelumpang Barat, Kabupaten Kotabaru, sedangkan sampel adalah nyamuk yang tertangkap.

\section{Penangkapan Nyamuk}

Penangkapan nyamuk dewasa dilakukan pada malam hari selama 12 jam (18.00-06.00 WITA) dengan metode umpan orang yaitu umpan orang dalam (UOD) dan umpan orang luar (UOL) oleh enam orang kader penangkap nyamuk pada tiga pondok (satu kader UOD dan satu kader UOL pada tiap pondok). Penangkapan dilakukan selama 40 menit untuk umpan orang dalam dan luar kemudian 10 menit untuk penangkapan di dinding dalam dan luar rumah serta di semak. Kegiatan penangkapan nyamuk disertai dengan pengukuran suhu dan kelembaban di dalam dan di luar rumah menggunakan termohygrometer.

\section{Identifikasi dan Pembedahan nyamuk}

Pembedahan ovarium nyamuk dilakukan dengan menggunakan jarum seksi di bawah mikroskop nikon ${ }^{\circledR}$ SMZ445 dengan pembesaran 10x. Nyamuk yang tertangkap dimasukkan ke dalam paper cup, kemudian di lakukan pembiusan menggunakan chloroform dan di identifikasi dengan menggunakan kunci identifikasi. ${ }^{13,14}$ Sebelumnya kaki dan sayap nyamuk dilepaskan terlebih dahulu agar tidak mengganggu saat pembedahan, kemudian ditambahkan tetesan aquadest dan diteteskan di atas kaca objek/slide. Setelah itu, nyamuk diletakkan ditas kaca objek yang telah diteteskan aquades. Abdomen segmen ketujuh ditarik dengan jarum seksi sampai ovariumnya kelihatan dan terendam. Setelah itu, ovarium dilihat dibawah mikroskop dengan pembesaran 40x. Parus jika pernah bertelur jika ditandai dengan tracheola terbuka dan nulliparous jika belum pernah bertelur ditandai dengan tracheola menggulung.

\section{Observasi Lingkungan}

Observasi lingkungan dan tempat/habitat perkembangbiakan Anopheles dilakukan pada sore hari untuk mendapatkan jenis habitat perkembangbiakan jentik, tumbuhan dan vegetasi, suhu dan $\mathrm{pH}$, serta pengambilan titik koordinat dengan GPS.

\section{Analisis Data}

Kepadatan nyamuk spesies tertentu dengan beberapa penangkapan penangkapan yang dinyatakan dalam kelimpahan nisbi. ${ }^{15}$

$$
\text { Kelimpa } \square \text { an Nisbi }=\frac{\text { Jumlah Individu Spesies Tertentu yang Ditangkap }}{\text { Jumlah Total Individu Nyamuk yang Tertangkap }} \times 100 \%
$$

Kepadatan populasi nyamuk dapat diketahui dari hasil penangkapan di daerah penelitian, maka data yang diperoleh dihitung menurut rumus yaitu ${ }^{15}$ :

$$
\begin{gathered}
\text { Man Hour Density }(\mathrm{MHD})=\frac{\text { Jumlah nyamuk yang ditangkap dengan umpan orang }}{\text { Lama penangkapan/ jam x Jlh penangkap x Jlh wkt penangkapan }} \\
\text { Man Bittting Rate }(\mathrm{MBR})=\frac{\text { Jumlah nyamuk yang ditangkap dengan umpan orang }}{\text { Lama penangkapan/ jam x Jumlah malam x Jumlah umpan orang }}
\end{gathered}
$$

Proporsi parus adalah persentase nyamuk yang pernah bertelur berdasarkan hasil pembedahan kelenjar ovari dalam suatu periode penangkapan.

$$
\text { Parity rate }=\frac{\text { Jumlah nyamuk pernah bertelur (parus) }}{\text { Jumlah nyamuk yang diperiksa ovariumnya }} \times 100 \%
$$

Peluang hidup nyamuk setiap hari yang dinyatakan dalam \% yang diperoleh dari suatu perhitungan matematis dengan mengetahui proporsi parus dan siklus gonotropik. ${ }^{16}$

Rumus $\rightarrow$ Peluang hidup $(P)=\sqrt[b]{d}$ $\mathrm{P}$ : peluang hidup nyamuk setiap hari

${ }^{\mathrm{b}}$ : siklus gonotropik (hari) $\mathrm{d}:$ Parus rate (porporsi nyamuk parus $=\%$ )

Hasil pengukuran : Peluang hidup nyamuk setiap hari (\%)

Umur relatif nyamuk di populasi adalah perkiraan umur nyamuk di populasi yang dinyatakan dalam hari, yang diperoleh melalui suatu perhitungan matematis dengan melakukan perhitungan setelah diketahuinya peluang hidup nyamuk setiap hari. ${ }^{17}$ 
Umur relatif di populasi $: \frac{1}{-\log \mathrm{e} p}$

$\log \mathrm{e} \quad$ : Bilangan matematis tertentu

$\mathrm{p} \quad$ : Peluang hidup nyamuk

\section{HASIL DAN PEMBAHASAN}

Jenis nyamuk yang tertangkap ada 7 Spesies yaitu Aedes vexans, Ae.albopictus, Culex quinquefasciatus, Cx. tritaeniorhynchus, Cx. vishnui, Mansonia dives dan Anopheles leucosphyrus.

Tabel 1. Ragam Jenis Nyamuk, Komposisi, Suhu dan Kelembaban di Desa Batang Kulur, Kecamatan Kelumpang Barat, Kabupaten Kotabaru

\begin{tabular}{|c|c|c|c|c|c|c|c|c|c|c|}
\hline No & Jam & 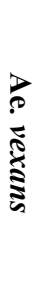 & 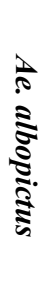 & 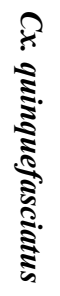 & 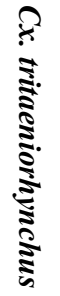 & 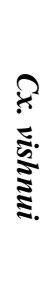 & 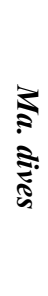 & 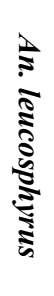 & Suhu $\left({ }^{0} \mathrm{C}\right)$ & $\begin{array}{c}\text { Kelembaban } \\
(\%)\end{array}$ \\
\hline 1 & $18.00-19.00$ & 2 & 0 & 0 & 0 & 0 & 0 & 0 & 28,4 & 85 \\
\hline 2 & $19.00-20.00$ & 1 & 1 & 1 & 0 & 0 & 0 & 0 & 28,4 & 85 \\
\hline 3 & $20.00-21.00$ & 2 & 0 & 0 & 1 & 0 & 0 & $\mathbf{0}$ & 27,9 & 85 \\
\hline 4 & $21.00-22.00$ & 2 & 0 & 0 & 0 & 0 & 0 & 2 & 27,3 & 87 \\
\hline 5 & $22.00-23.00$ & 1 & 0 & 1 & 5 & 1 & 0 & 6 & 27 & 90 \\
\hline 6 & $23.00-24.00$ & 2 & 0 & 1 & 1 & 0 & 1 & 3 & 26,9 & 91 \\
\hline 7 & $24.00-01.00$ & 2 & 0 & 2 & 2 & 0 & 0 & 1 & 26,9 & 89 \\
\hline 8 & $01.00-02.00$ & 1 & 0 & 1 & 5 & 0 & 0 & 1 & 26,8 & 89 \\
\hline 9 & $02.00-03.00$ & 1 & 0 & 2 & 2 & 0 & 0 & 0 & 26,7 & 91 \\
\hline 10 & $03.00-04.00$ & 1 & 0 & 3 & 0 & 1 & 0 & 0 & 26,5 & 91 \\
\hline 11 & $04.00-05.00$ & 0 & 0 & 2 & 4 & 0 & 0 & 2 & 26,1 & 91 \\
\hline \multirow[t]{2}{*}{12} & $05.00-06.00$ & 0 & 0 & 0 & 1 & 1 & 1 & 1 & 26,1 & 91 \\
\hline & Jumlah & 15 & 1 & 13 & 21 & 3 & 2 & 16 & & \\
\hline
\end{tabular}

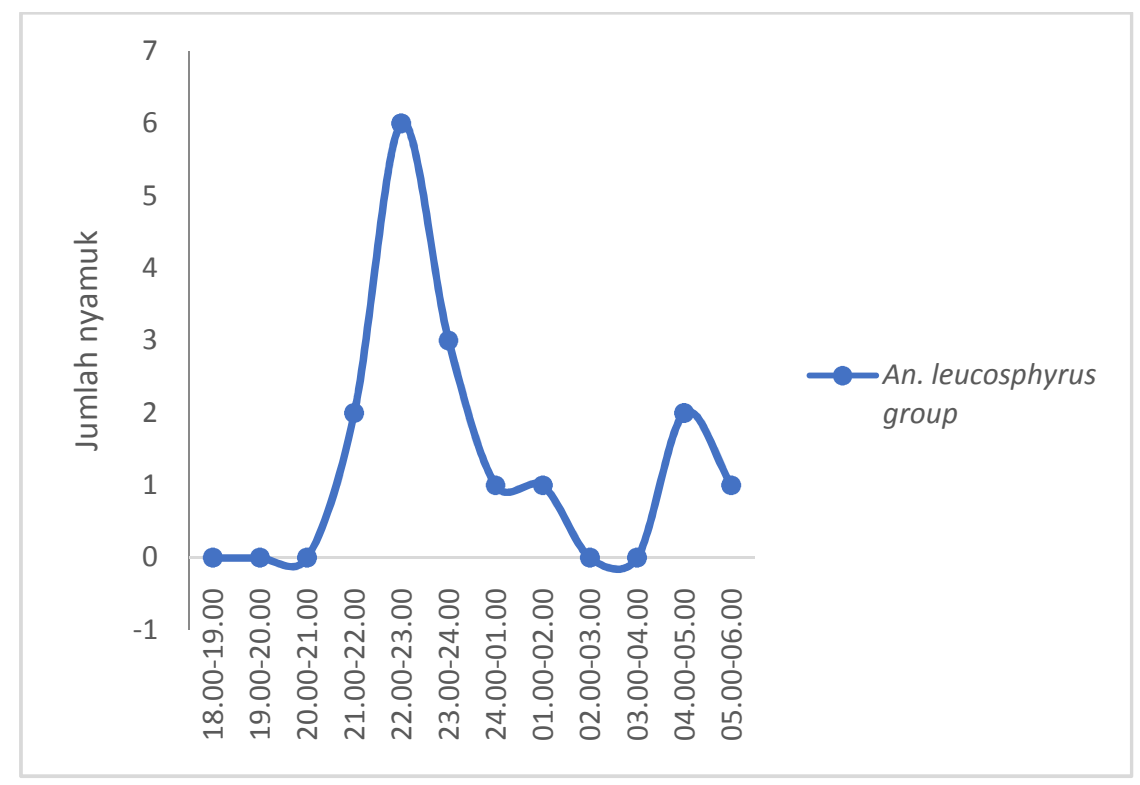

Gambar 1. Fluktuasi nyamuk Anopheles leucosphyrus dengan umpan orang di Desa Batang Kulur Kecamatan Kelumpang Barat, Kabupaten Kotabaru

Nyamuk mempunyai fluktuasi yang berbeda Jumlah nyamuk terbanyak adalah $C x$. untuk setiap spesies dan tempat. Anopheles tritaeniorhynchus, An. leucosphyrus dan Ae. vexans . leucosphyrus mulai muncul pada jam 22.00 dan Nilai kepadatan perjam (MHD) secara berurutan yaitu kembali meningkat pada jam 04.00 (Gambar 1). 0,39 org/jam/hari, 0,30 org/jam/hari dan 0,28 
org/jam/hari, sedangkan nilai kepadatan perhari yaitu 3,50 orang/hari, 2,67 orang/hari dan 2,50 orang/hari.

Tabel 2. Jumlah Nyamuk yang Tertangkap, Kepadatan nyamuk, Kelimpahan Nisbi dan Dominasi Spesies

\begin{tabular}{clcccc}
\hline \multirow{2}{*}{ No } & \multirow{2}{*}{ Jumlah Perspesies } & \multirow{2}{*}{ Jumlah } & \multicolumn{2}{c}{ Kepadatan nyamuk } & \multirow{2}{*}{ KN*** } \\
\cline { 4 - 5 } & & & $\mathbf{M H D} *$ & $\mathbf{M B R}^{* *}$ & \\
\hline $\mathbf{1}$ & Ae. vexans & 15 & 0,28 & 2,50 & 0,21 \\
$\mathbf{2}$ & Ae. albopictus & 1 & 0,02 & 0,17 & 0,01 \\
$\mathbf{3}$ & Cx. quinquefasciatus & 13 & 0,24 & 2,17 & 0,19 \\
$\mathbf{4}$ & Cx. tritaeniorhynchus & 21 & 0,39 & 3,50 & 0,30 \\
$\mathbf{5}$ & An. leucosphyrus & $\mathbf{1 6}$ & $\mathbf{0 , 3 0}$ & $\mathbf{2 , 6 7}$ & $\mathbf{0 , 2 3}$ \\
$\mathbf{6}$ & Cx. vishnui & 3 & 0,06 & 0,50 & 0,04 \\
7 & Ma. dives & 1 & 0,02 & 0,17 & 0,01 \\
\hline
\end{tabular}

*MHD : Kepadatan nyamuk menghisap darah perorang/jam/spesies,

**MBR : Kepadatan nyamuk menghisap darah perorang/hari/spesies

$* * * \mathrm{KN}$ : kelimpahan Nisbi

Tabel 3. Jumlah An. leucosphyrus di Dalam dan di Luar Rumah, Parous Dan Perkiraan Umur Nyamuk

\begin{tabular}{cccc}
\hline \multirow{2}{*}{ No } & \multirow{2}{*}{ Jam } & \multicolumn{2}{c}{ An. leucosphyrus gruop } \\
\cline { 2 - 4 } $\mathbf{1}$ & $18.00-19.00$ & 0 & Luar \\
$\mathbf{2}$ & $19.00-20.00$ & 0 & 0 \\
$\mathbf{3}$ & $20.00-21.00$ & 0 & 0 \\
$\mathbf{4}$ & $21.00-22.00$ & 1 & 1 \\
$\mathbf{5}$ & $22.00-23.00$ & 5 & 1 \\
$\mathbf{6}$ & $23.00-24.00$ & 2 & 1 \\
$\mathbf{7}$ & $24.00-01.00$ & 0 & 1 \\
$\mathbf{8}$ & $01.00-02.00$ & 1 & 0 \\
$\mathbf{9}$ & $02.00-03.00$ & 0 & 0 \\
$\mathbf{1 0}$ & $03.00-04.00$ & 0 & 0 \\
$\mathbf{1 1}$ & $04.00-05.00$ & 2 & \\
$\mathbf{1 2}$ & $05.00-06.00$ & 0 & \\
\hline & Jumlah & 11 & \\
\hline
\end{tabular}

Parus : Nyamuk yang sudah pernah bertelur,

Luar : penangkapan di Luar rumah,

Dalam: Penangkapan di dalam Rumah

Tabel 4. Macam Perindukan Nyamuk, Koordinat dan indicator Air di Desa Batang Kulur, Kecamatan

Kelumpang Barat, Kab. Kotabaru

\begin{tabular}{|c|c|c|c|c|c|c|c|c|}
\hline \multirow{2}{*}{ No } & \multicolumn{2}{|c|}{ Koordinat } & \multirow{2}{*}{$\begin{array}{c}\text { Macam } \\
\text { Perindukan }\end{array}$} & \multirow{2}{*}{ Tanaman air } & \multirow{2}{*}{ Salinitas } & \multirow{2}{*}{ pH } & \multirow{2}{*}{ Suhu } & \multirow{2}{*}{ Jenis larva } \\
\hline & $\mathrm{S}$ & $\mathrm{E}$ & & & & & & \\
\hline 1 & 02.84336 & 116.05051 & Kolam & Lumut hijau, ganggang & 0 & 7,8 & 27,6 & Culex, Anopheles \\
\hline 2 & 02.84397 & 116.05051 & Mata air & - & 0 & 7,2 & 27,7 & - \\
\hline 3 & 02.84302 & 116.05023 & Kolam & Lumut hijau, ganggang & 0 & 7,2 & 28,1 & Culex, Anopheles \\
\hline
\end{tabular}

Pada Tabel 3 dapat di ketahui bahwa $A n$. leucosphyrus lebih banyak menghisap darah di luar rumah pada jam 22.00. umumnya parus (sudah pernah bertelur) dengan perkiraan umur 21,54 hari dan peluang hidup $95 \%$.

Habitat perkembang biakan nyamuk yang ditemukan ada 2 yaitu kolam dan mata air. Larva yang ditemukan yaitu Culex dan Anopheles. Tanaman air yang ditemukan salah satunya adalah lumut hijau yang merupakan sumber makanan larva.
Jenis nyamuk dengan jumlah tertangkap yang terbanyak adalah $C x$. tritaeniorhynchus, An. leucosphyrus dan Ae. vexans . Nilai kepadatan perjam (MHD) secara berurutan yaitu 0,39, 0,30 dan 0,28, sedangkan nilai kepadatan permalam (MBR) yaitu 3,50, 2,67 dan 2,50. Berdasarkan Permenkes nomor 50 tahun 2017 tentang Standar Baku Mutu Kesehatan Lingkungan dan Persyaratan Kesehatan untuk Vektor dan Binatang Pembawa Penyakit Serta Pengendaliannya, nilai MBR Anopheles harus kurang dari $0,025,{ }^{18}$ sedangkan di Desa Batang Kulur adalah 
2,67 artinya sudah melebihi dari kepadatan yang di persyaratkan. Spesies nyamuk Anopheles dapat ditetapkan sebagai vektor malaria apabila memenuhi beberapa persyaratan diantaranya umur nyamuk cukup panjang, mempunyai kepadatan tinggi sehingga frekuensi menggigit inang juga tinggi, lebih cenderung memangsa manusia, dan adanya sporozoit pada tubuh nyamuk. ${ }^{19}$

Nyamuk Anopheles yang tertangkap pada penelitian adalah dari jenis An. leucosphyrus. Anopheles leucosphyrus merupakan nyamuk yang banyak ditemukan di habitat hutan dan pemukiman sekitar hutan. Anopheles leucosphyrus mempunyai beberapa spesies yaitu An. latens, An. cracens, An. scanloni, An. baimaii, An. mirans, An. recens, An. balabacensis, An. introlatus, dan An. leucosphyrus. An. Pujutensis, An. Recens dan An. Sulawesi. ${ }^{20}$ Beberapa spesies yang sudah menjadi vektor malaria pada manusia adalah: An. baimaii [Bangladesh, Cina (Yunnan), India (Andamans, Assam, Meghalaya, Benggala Barat), Myanmar, Thailand]; An. latens [Kalimantan (Indonesia)], Semenanjung Malaysia, Thailand]; An. cracens (Sumatra, Semenanjung Malaysia, Thailand); An. scanloni (Thailand); An. elegans (Ghat Barat India); An. recens (Sumatra) atau An. mirans [Sri Lanka dan India barat daya (Karnataka, Kerala, Tamil Nadu)], yang juga merupakan vektor alami malaria simian/primate bersama dengan An. balabacensis, An. dirus dan An. leucosphyrus. $^{20}$

Fluktuasi aktifitas Anopheles leucosphyrus pada penelitian ini mulai terlihat pada jam 21.00, mencapai puncaknya pada jam 22.00, setelah itu semakin menurun namun kembali mengalami peningkatan pada jam 04.00. Hasil penelitian terdahulu pada waktu dan wilayah berbeda di Kabupaten Kotabaru menunjukkan An. leucosphyrus ditemukan pada pukul 18.00-19.00, 21.00- 22.00 dan 23.00-24.00 dengan kepadatan tertinggi pada pukul 18.00-19.00. ${ }^{21}$ Secara umum nyamuk Nyamuk Anopheles selama ini dikenal bersifat nokturnal, yaitu beraktifitas mencari makan sumber darah pada malam hari, meskipun tidak pada waktu yang bersamaan, ada yang mempunyai puncak kepadatan populasi pada sore hari ketika matahari baru saja terbenam, atau pada tengah malam ataupun ketika matahari akan terbit. $^{22}$ Perbedaan hasil tersebut dapat terjadi dikarenakan aktifitas nyamuk sangat dipengaruhi oleh faktor lingkungan antara lain suhu, kelembapan dan kecepatan angin. ${ }^{23,24}$ Lokasi penangkapan nyamuk merupakan daerah yang baru saja dilakukan pembukaan lahan dan berdekatan dengan barak pekerja pembangunan pabrik pengolahan kelapa sawit, sebagian pekerja juga beraktifitas pada malam hari. Dengan diketahui fluktuasi nyamuk Anopheles di wilayah tersebut, perilaku atau aktiftas masyarakat sekitar yang berisiko pada jam tersebut perlu ditiadakan atau dicari alternatif untuk melakukan proteksi diri dari gigitan nyamuk.
Berdasarkan Tabel 3 dapat di ketahui bahwa An. leucosphyrus bersifat eksofilik yaitu lebih banyak menghisap darah di luar rumah pada jam 22.00. umumnya parous (sudah pernah bertelur) dengan perkiraan umur 21,54 hari dan peluang hidup 95\%. Peluang nyamuk menjadi vektor di Desa Batang Kulur sangat besar mengingat umurnya lebih dari 15 hari. Masa inkubasi Plasmodium falcifarum adalah yang paling lama dibandingkan dengan plasmodium yang lain di tubuh nyamuk. ${ }^{25}$ Plasmodium falcifarum perlu waktu hingga 14 hari untuk menjadi infektif dan masuk di kelenjar ludah nyamuk dan menjadi tahap sporozoit. Kondisi alam berupa suhu dan kelembaban yang optimum, serta ada/tidaknya predator alami dapat mempengaruhi peluang hidup nyamuk di alam. $^{26}$ Peluang hidup An. leucosphyrus di Desa Batang Kulur sangat optimum karena lebih dari 90\% (yaitu 95\%), sehingga nyamuk mampu mempunyai umur yang lama untuk melakukan aktifitas dan bererproduksi. $^{27}$

Siklus kehidupan nyamuk sangat ditentukan oleh kondisi habitat lingkungan yang ada seperti suhu, kelembapan, curah hujan, salinitas, $\mathrm{pH}$, oksigen terlarut, keberadaan tumbuhan air dan hewan air lainnya. ${ }^{28}$ Habitat perkembangbiakan nyamuk yang ditemukan ada 2 yaitu kolam dan mata air. Larva yang ditemukan yaitu Culex dan Anopheles. Tanaman air yang ditemukan salah satunya adalah lumut hijau yang merupakan sumber makanan larva. Anopheles leucosphyrus mempunyai habitat di hutan atau disekitar habitat hutan. ${ }^{29}$ Fungsi vegetasi dalam habitat perkembangbiakan nyamuk pada umumnya sebagai pelindung larva dari serangan predator dan sebagai makanan pada larva tersebut khususnya pada lumut. ${ }^{30}$ Tempat ditemukan larva biasanya di mata air dan sekitar pinggir sungai yang tenang pada suhu $24,10^{\circ} \mathrm{C}-27,15^{\circ} \mathrm{C}$ dan $\mathrm{pH} 7,13-7,2 .^{31}$ Hal tersebut sesuai dengan yang ditemukan di Desa Batang Kulur yaitu suhu 27,6 - 28,1 dan ph 7,2 -7,8, yang mengindikasikan bahwa lingkungan habitat tersebut sangat cocok untuk perkembangbiakannya. Tidak ditemukannya predator larva semakin memungkinkan nyamuk untuk berkembang biak dengan baik di habitat tersebut.

Upaya penurunan kasus malaria secara terpadu tidak bisa hanya mengandalkan upaya dari pihak Puskesmas dan Dinas Kesehatan. Keberhasilan pengendalian akan lebih cepat jika terjadi dukungan dari sektor masyarakat dan industri yang berada disekitarnya. Beberapa faktor risiko malaria sebenarnya dapat dikurangi dengan penyuluhan karena secara umum permasalahannya adalah terbukanya peluang terhadap gigitan nyamuk. ${ }^{32}$ Pencegahan terhadap faktor risiko juga perlu dilakukan baik secara kelompok maupun perorangan seperti tidak keluar pada malam hari jika tidak perlu, penggunaan kelambu pada saat tidur dan penanganan tempat habitat larva serta pengobatan secara tuntas.

\section{SIMPULAN}


Spesies dan komposisi nyamuk yang ditemukan yaitu Aedes vexans, Ae.albopictus, Culex quinquefasciatus, Cx. tritaeniorhynchus, Cx. vishnui, Mansonia dives dan Anopheles leucosphyrus. Kepadatan Nyamuk Anopheles leucosphyrus sebagai tersangka vektor malaria di Desa Batang Kulur dengan nilai kepadatan perjam (MHD) 0,30/orang/jam, sedangkan nilai kepadatan permalam yaitu 2,67/orang/malam. Peluang hidup perhari 95\% serta perkiraan umur populasi 21,54 hari. Fluktuasi Anopheles leucosphyrus mulai muncul pada jam 22.00 dan kembali meningkat pada jam 04.00, lebih sering ditemukan di luar rumah. Habitat perkembang biakan nyamuk yang ditemukan yaitu kolam. Dengan ditemukannya habitat yang mendukung dan peluang hidup 95\% sehingga Desa Batang Kulur merupakan daerah yang cocok untuk perkembangan vektor malaria.

\section{DAFTAR PUSTAKA}

1. Cowman AF, Healer J, Marapana D, Marsh K. Review Malaria: Biology and Disease. Cell [Internet]. 2016;167(3):610-24. Available from: https://doi.org/10.1016/j.cell.2016.07.055

2. Kementerian Kesehatan RI. Data Malaria di Indonesia Tahun 2018. Jakarta, Indonesia: Subdit Malaria Ditjen P2P Kemenkes; 2018.

3. Sitohang V, Sariwati E, Fajariyani SB, Hwang D, Kurnia B, Hapsari RK, et al. Comment Malaria elimination in Indonesia : halfway there. Lancet Glob Heal [Internet]. 2018;6(6):e604-6. Available from: https://doi.org/10.1016/S2214109X(18)30198-0

4. Kenterian Kesehatan Republik Indonesia. InfoDatin-Malaria-2016.pdf. Jakarta, Indonesia: Pusdatin Kemenkes RI; 2018.

5. Dinas Kesehatan Provinsi Kalimantan Selatan. Evaluasi Capaian Kinerja P2 Malaria Di Kalsel Dan Perencanaan Kegiatan Tahun 2019. Banjarmasin, Indonesia; 2019.

6. Kp P, Af R, Mb T, Beck-johnson LM, Nelson WA, Paaijmans $\mathrm{P}$, et al. The importance of temperature fluctuations in understanding mosquito population dynamics and malaria risk Subject Areas: R Soc Open Sci. 2017;4(3):160969.https://doi.org/10.1098/rsos.1 60969

7. Tyrrell MB, Verdonck K, Muela SH, Gryseels C. Defining micro $\square$ epidemiology for malaria elimination: systematic review and meta $\square$ analysis. Malar J. 2017;16(1):1-20. https://doi.org/10.1186/s12936-017-17921.PMid:28427389 PMCid:PMC5399382

8. Elyazar, Iqbal RF et al. The distribution and bionomics of Anopheles malaria vector mosquitoes in Indonesia. Adv Parasitol. 2013;83:173-266. https://doi.org/10.1016/B9780-12-407705-8.00003-3.PMid:23876873

9. Indriyati L, Andiarsa D, Hairani B. Vektor Malaria Baru di Kabupaten Kotabaru, Provinsi
Kalimantan Selatan , Indonesia. Vektora. 2017;9(1):1-8.

https://doi.org/10.22435/vk.v9i1.4522.1-8

10. Juhairiyah J, Andiarsa D, Indriyati L, Ridha MR, Prasodjo RS, Dhewantara PW. Spatial analysis of malaria in Kotabaru, South Kalimantan, Indonesia: an evaluation to guide elimination strategies. Trans R Soc Trop Med Hyg. 2020; https://doi.org/10.1093/trstmh/traa125.PMid:331 69161

11. Harbach RE, Baimai V, Sukowati S. Some observations on sympatric populations of the malaria vectors Anopheles leucosphyrus and Anopheles balabacensis in a village-forest setting in South Kalimantan. Southeast Asian J Trop Med Public Heal. 1987;18(2):241-7.

12. Moyes CL, Shearer FM, Huang Z, Wiebe A, Gibson HS, Nijman V, et al. Predicting the geographical distributions of the macaque hosts and mosquito vectors of Plasmodium knowlesi malaria in forested and non-forested areas. Parasit Vectors. 2016;9(1):1-12. https://doi.org/10.1186/s13071-016-15270.PMid:27125995 PMCid:PMC4850754

13. O'Connor CT, Soepanto A. Kunci Bergambar Nyamuk Anopheles Dewasa di Indonesia. Jakarta: Direktorat Jenderal Pemberantasan Penyakit Menular dan Penyehatan Lingkungan, Departemen Kesehatan RI; 1999.

14. Rattanarithikul, Rampa. Harbach, Ralph E. Harrison, Bruce. Panthusiri P, Coleman RE and JHR. Illustrated Keys to the Medically Important Mosquitoes of Thailand. SEAMEO Reg Trop Med Public Heal Netw. 2010;41(1):1-66.

15. Kemenkes R. Permenkes No 50 Tahun 2017 tentang Standar Baku Mutu Kesehatan Lingkungan Dan Persyaratan Kesehatan Untuk Vektor Dan Binatang Pembawa Penyakit Serta Pengendaliannya. 2017.

16. Draper CC, Davidson G. A new method of estimating the survival-rate of anopheline mosquitoes in nature [13]. Vol. 172, Nature. 1953.p.

503.https://doi.org/10.1038/172503a0.PMid:130 99249

17. Davidson G. Estimation of the Survival-Rate of Anopheline Mosquitoes. Nat Publ Gr. 1954; https://doi.org/10.1038/174792a0.PMid:1321400 9

18. Kementerian Kesehatan Republik Indonesia. Peraturan Menteri Kesehatan Republik Indonesia Nomor 50 Tahun 2017 Tentang Standar Baku Mutu Kesehatan Lingkungan dan Persyaratan Kesehatan untuk Vektor dan Binatang Pembawa Penyakit. 2017 p. 1-82.

19. Budiyanto A, Ambarita LP, Salim M. Konfirmasi Anopheles sinensis dan Anopheles vagus sebagai Vektor Malaria di Kabupaten Muara Enim Provinsi Sumatera Selatan. ASPIRATOR - J Vector-borne Dis Stud. 
2017;9(2):51-60.

https://doi.org/10.22435/aspirator.v9i2.5998.5160

20. Sallum MAM, Peyton EL, Harrison BA, Wilkerson RC. Revision of the Leucosphyrus group of Anopheles (Cellia) (Diptera, Culicidae). Rev Bras Entomol [Internet]. 2005;49(Peyton

152.https://doi.org/10.1590/S008556262005000500001

21. Indriyati L, Yuana WT, Andiarsa D. Gambaran Hasil Spot Survei Nyamuk Anopheles sp . di Tambang Emas Kura-Kura Banian , Kabupaten Kotabaru , Kalimantan Selatan. J Vektor Penyakit. 2016;10(2):3944.https://doi.org/10.22435/vektorp.v10i2.6257. $39-44$

22. Shinta P, Baharudin A. Perilaku Menghisap Darah Nyamuk Anopheles spp. di Desa Saketa, Kecamatan Gane Barat, Halmahera Selatan, Maluku Utara. J Ekol Kesehat. 2019;18(2):99110.https://doi.org/10.22435/jek.18.2.2079.99110

23. Kawulur HSI, Ayomi I, Suebu M, Rokhmad MF, Pardi MR. Pengaruh Faktor Klimatik Terhadap Kepadatan Nyamuk Anopheles farauti di Ekosistem Pantai dan Rawa Provinsi Papua. J Biol Papua. 2019;11(2):729.https://doi.org/10.31957/jbp.945

24. Arifianto RP, Masruroh D, Habib MJ, Wibisono MG, Wathon S, Oktarianti R, et al. Identifikasi dan Analisis Bionomik Vektor Malaria Anopheles sp. di Desa Bangsring Kecamatan Wongsorejo, Banyuwangi. Acta Vet Indones. 2018;6(1):44-

50.https://doi.org/10.29244/avi.6.1.44-50

25. Elliott R. The influence of vector behavior on malaria transmission. Am J Trop Med Hyg. 1972;21(5 Suppl):75563.https://doi.org/10.4269/ajtmh.1972.21.755.P Mid:4561523

26. Eckhoff PA. A malaria transmission-directed model of mosquito life cycle and ecology. Malar J. 2011;10(1):1-17.https://doi.org/10.1186/14752875-10-303.PMid:21999664

PMCid:PMC3224385

27. Coluzzi M. Malaria Vector Analysis and Control. 1992;8(4).https://doi.org/10.1016/01694758(92)90277-9

28. Pratama GY. Nyamuk Anopheles Sp dan Faktor Yang Mempengaruhi Di Kecamatan Rajabasa, Lampung Selatan. J Major. 2015;4(1):207.https://doi.org/10.15408/ess.v4i2.1966

29. Tainchum K, Kongmee M, Manguin S, Bangs MJ, Chareonviriyaphap T. Anopheles species diversity and distribution of the malaria vectors of Thailand. Trends Parasitol [Internet]. 2015;31(3):109-19. Available from: https://doi.org/10.1016/j.pt.2015.01.004.PMid:2 5697632
30. Tallan MM, Mau F. Karakteristik Habitat Perkembangbiakan Vektor Filariasis di Kecamatan Kodi Balaghar Kabupaten Sumba Barat Daya. ASPIRATOR - J Vector-borne Dis Stud. 2016;8(2):5562.https://doi.org/10.22435/aspirator.v8i2.4243.5 $5-62$

31. Santoso NB, Hadi KU, Sigit SH, Koesharto FX. Karakteristik Habitat Larva Anopheles maculatus \& Anopheles balabacencis Di daerah Endemik Malaria Kecamatan Kokap Kulonprogo Daerah Istimewa Yogyakarta. IPB University; 2001.

32. Rahayu N, Hidayat S, Sulasmi S, Suryatinah Y. Kontribusi pekerja hutan terhadap kejadian malaria di Desa Temunih Kecamatan Kusan Hulu Kabupaten Tanah Bumbu Provinsi Kalimantan Selatan Contribution of forest worker to malaria incident in Temunih Villages of Kusan Hulu Subdistrict, Tanah Bumbu Distric. J. Health Epidemiol Commun Dis. 2016;2(2):42-51. 